Seloka: Jurnal Pendidikan Bahasa dan Sastra Indonesia
$9(2)(2020): 99-109$
UNNES
https://journal.unnes.ac.id/sju/index.php/seloka

\title{
The Images and The Struggle of The 2018 Central-Java Local Government Election Reporting Meaning in Online Media
}

\author{
Anung Anindita ${ }^{1 凶}$, Hari Bakti Mardikantoro ${ }^{2}$,Bernadus Wahyudi Joko Santoso ${ }^{2}$ \\ DOI : https://doi.org/10.15294/seloka.v9i2.39062 \\ 1. SMP Negeri 21 Semarang, Indonesia \\ 2. Universitas Negeri Semarang, Indonesia
}

\begin{tabular}{l} 
Article Info \\
\hline History Articles \\
Received: \\
6 February 2020 \\
Accepted: \\
5 June 2020 \\
Published: \\
21 August 2020 \\
\hline Keywords: \\
images, social actor, \\
local election, Theo \\
van Leeuwen
\end{tabular}

\begin{abstract}
The role of online media is really essential in society because it fosters and encourages the public opinion. Therefore, online media could be the most effective interest mean to achieve certain massive purposes, including the reports of certain actor's images. It allows social actor's images to not being reported objectively but instead processed and managed. Thus, it could be said there is a correlation between the language and the domination in the discourse practice to create ideologies with certain purposes. The point, the mass media has its specific powers to control its information display so its neutrality in the mass media is doubtful. So as this research, the images of social actor's images, the candidate of Central-Java election 2018, become the focused problems to analyze by Theo van Leeuwen theory. The data sample was obtained from the report discourse in online mass media, such as Kumparan.com, Tribunnews.com, and Sindonews.com about the Central-Java Election 2018, from April-June 2018. The analysis was based on the deletion strategy in which covered suppression and backgrounding. The results showed that Kumparan.com tended to apply suppression in merging the social actors, Ganjar Pranowo-Taj Yasin and backgrounding in the form of a phrase "politikus PDIP, mantan anggota DPR RI yang diperiksa KPK". (The PDIP politician, the ex of the House whom is investigated by Corruption Eradication Comission). Meanwhile, Tribunnews.com applied backgrounding in the form of "sang petahana" or "incumbent", meanwhile Sindonews.com did not either put certain social actors in advantage nor marginalize them.
\end{abstract}

\footnotetext{
$凶$ Correspondence address:

Jl. Kr. Rejo Raya No.12, Srondol Wetan, Kec. Banyumanik, Kota

Semarang, Jawa Tengah 50264

p-ISSN 2301-6744

E-mail: ditaanindita19@gmail.com

e-ISSN 2502-4493
} 


\section{INTRODUCTION}

A language, as a communication mean, is not only represented as utterances but also gestures with purpose to let speech partners understand of something. In this case, the language with its communicative functions, in fact could be used, manipulated, and packaged specifically to achieve certain purposes. Thus, there is a need of criticisms by not only reviewing the internal relationship but also the external relationship. Therefore, a discourse analysis as a method to find out the language use does not only rely on the grammatical rules but also its larger rules which involves a very essential social situation (Sobur, 2012).

Based on the explanation, it could be said that the critical perspective has important roles in analyzing a language. Being critical in this case is to show the possibly-hidden relationship among people, such as the language, domination, and ideology relationships. Thus, it needs critical language study (CLS) to analyze the social relationship which is focused on its linguistics elements. They are expressed to show some implicit hints in social relationship system and the implicit effects that they might have in the system (Fairclough, 2003). Therefore, it could be said that being critical means analyzing the discourse by considering its communicative elements in a broader and various perspective, such as by involving social, cultural, and historical elements. It means a language is an intransparent delivery mode. There are distortions in delivering each notion. The statement is supported by Assidik (2016) that a language is made of interest and certain intention. In this case, the most frequently used language fosters a community assumption. It means inside of the language, there is a power.

Dealing with the explained matters, there is a need of specific understanding to understand the social dimension in a mass media. It is due to several language practices are intentionally "managed" by reporters with any technical and political reasons (Alwasilah, 1997). The statement is strengthened by Santoso (2018) that reports in online media are not always neutral.
There are excluded actors from the reports or, in another case, the dominant social actors are intentionally reported (included).

Therefore, there is a need of a critical discourse analysis. In this case, it deals with the image reports of Central-Java government election candidate 2018 in three online media. As what Hariyani argues (2016) that a political event always attracts attentions of mass media Therefore, in this analysis, a historical situatedness is also emphasized for all social event occurrence (Denzin, 2000). Therefore, it could be said that a history is a part of discourse's meaning in a mass media report that cannot be separated one to another.

The critical discourse analysis leads to Theo van Leeuwen's theory. According to Hasanah (2017), the task of mass media is to construct realities so the dominant and interest influences could be indicators of group marginalization or certain actors in an online media report. Moreover, the focus of Theo van Leeuwen's critical discourse analysis are the positive and negative images shown by mass media so that there would be a struggle of meanings between groups or an actor to another actor. As Littlejohn argues (2002) that a text media has ideological nature. Therefore, in this critical discourse analysis, it is also considered that mass media is a part of the interest conveying packages, such as the capital owners, the state, or the other. Therefore, a mass media is called as the dominant mean and the community hegemony will produce a bias or distorted reality done by certain social actors.

Based on the explanation, it could be said that reality of the same event may be realized by different manners in the mass media. It is same with Dinastiti's notions (2016) that there are different packages of discourses in each newspaper which is inevitability. It is because a language is a set of regulation system and a siding option (Alwasilah, 1997). Therefore, the matter to consider is the real meaning which cannot be separated from the social battle. It means there is always a constructed meaning done by certain groups to get positive images. A relevant study was done by Bustam (2013), titled 
"The Exclusion Strategies Of The Representation Of Social Actors In The Case Of FPI's Rejection To Lady Gaga's Performance In Indonesia On The Jakarta Post Newspaper Headlines (A Cda Approach)". This research determined the exclusion strategy applied by an English Newspaper in Indonesia, the Jakarta Post in representing the social actor to deal with FPI's rejection case toward Lady Gaga's performance in Indonesia. The applied strategy was a part of Theo van Leeuwen CDA model. There were two types of exclusions namely suppression and backgrounding. The results proved that the suppression of the Jakarta Post wanted to attract its readers' attentions to the "victimized" actor, Lady Gaga.

The next relevant study was done by Bestari (2014), titled "Pemberitaan Gubernur Bali, Mangku Pastika, dalam Surat Kabar Bali Post: Analisis Strategi". This research described the exclusion and inclusion strategies in Bali Post media dealing with the Bali governor's report, Mangku Pastika. The scope of the study only dealt with Bali Post which contained the figure of Bali's governor, Mangku Pastika as reported from September 19, 2011 until July 21, 2012. Meanwhile, the research objects were the exclusion-inclusion strategies applied by Bali Post in reporting the governor, Mangku Pastika. Theo van Leeuwen's theory applies the exclusion and inclusion approaches to analyze how actors in a discourse are shown.

Then, a research done by Mayasari (2014) titled "Tweet Farhat Abbas dalam Akun Twitter Pribadi Farhat Abbas: Analisis Wacana". The applied method was the descriptive-qualitative method with Theo van Leeuwen discourse analysis model. The findings showed (1) Farhat Abbas' tweet contained the discourse representation strategy which applied certain discourse instruments, such as inclusion, language style, presupposition, and modality. (2) Socially, Farhat used psychological principles, such as chaos, leverage, wave, and butterfly effect. The applied method in this research is the same as the research, Theo van Leeuwen Critical Discourse Analysis.

The next research was done by Ritongga (2014) titled "Pertarungan Makna pada
Konvensi Parti Demokrat dalam Mencari Calon Presiden Republik Indonesia". This research aims to investigate the struggle of meaning done by the conglomerates of Dahlan Iskan media in constructing the meanings about them to win over the national election campaign in the Democrat Party's convention. The results consisted of Radar Bandung and Bandung Express news media plus all Jawa Pos network newspaper member, through their reporting structures had become a dominating mean for Dahlan Iskan to construct his images during the campaign. It showed that Dahlan's struggle of meaning was basically a domination upon resources or a symbolic capital done by the media owner toward the symbols in the media, in the form of semiotic mastery.

Another study was done by Mardikantoro (2014) titled "Analisis Wacana Kritis pada Tajuk (Anti) Korupsi di Surat Kabar Berbahasa Indonesia". This research aimed to describe the attitudes and the perspective of the newspaper toward the corruption cases in Indonesia. They were realized into an (anti) corruption header discourse. The newspaper's attitudes are realized through two frames: criticizing corruption news and supporting corruption news. The critical discourse analysis in the header contained an (anti) corruption topic as an effort to reveal the hidden intention of the author. The results showed there were frames criticizing the corruption news, such as Tempo which disagreed with the corruption news. Furthermore, there were frames supporting the corruption news, such as Kompas, Republika, Koran Tempo, Jawa Pos, and Suara Merdeka which had attitudes and perspective to agree and support the corruption news.

The other study was done by Ghafur (2016) titled "Critical Discourse Analisys; Sebuah Model Analisis Sosial Kritis dalam Teks Media". The author expected to see the domination of the text further, to find the interesting concept about the media power, and to reveal the implicit meaning by having critical perspectives toward the discourse of Kompas mass media. It is explained several models in a discourse analysis, one of them is Theo van 
Leeuwen. It has correlations to image strategy of actors in a report text both exclusively and inclusively. There are several strategies in presenting the exposed information: (1) title selection, (2) vocabulary, (3) transitivity system, (4) nominalization structure, (5) modality, (6) speech act, and (7) metaphor.

\section{The Analysis Strategy of Social Actors}

According to Theo van Leeuwen's analysis, to analyze the social actor image needs a transformation strategy. In this case, the transformation is divided by several elements as follow.

\section{Deletion}

It is re-contextualization or new interpretation provision by involving social practices (Leeuwen, 2008). In this case, there are intentionally-omitted social actors, being not explicit, with certain purposes done by the certain dominant groups. Deletion in Theo van Leeuwen's analysis consists of system 1 and 2 . They are exclusion and inclusion.

\section{The Struggles of Meaning}

According to Louw (2001), struggle of domination is also called struggle of meanings. Basically, a domination is obtained from three things: access to the resource, certain social position, and a language as a regulating agent and a space which typically consists of symbolic power. The meaning structure is as a constructing form. The struggle of meaning occurs within these three factors. Media, as if it was a building of public thoughts in a semiotic correlation, is assumed as a media production. Meanings and domination correlation emerge from the meaning struggle process. This process aims to coagulate certain meanings and structures if they provide advantages for their positions (Louw, 2005).

\section{METHOD}

There are two applied approaches in this research: theoretical and methodological approaches. The applied theoretical approach is
Theo van Leeuwen's critical discourse analysis theory. Meanwhile, the applied methodological approach is the qualitative-descriptive approach. The data collection technique was done by listening method. The listening method consists of a basic technique - it deals with a recording technique and advance techniques. The first advance technique is to listen the conversation. The second advance technique is to observe the conversation. The third advance technique is recording while the fourth technique is noting (Sudaryanto, 2015). The applied techniques in this research were the observationalconversation and noting techniques.

The obtained data were tested in term of their validity by triangulating them. The data analysis was done in three stages, consisting of description, interpretation, and explanation based on Theo van Leeuwen's critical discourse analysis model. This critical discourse analysis model has purposes to reveal the images and meaning struggles of the social actors in the text.

\section{RESULTS AND DISCUSSIONS}

The image captures of the candidates from the mass media reports were absolutely followed by specific strategies. It was proved by the various report content packages with same topic base or by the existence of marginalizing process for certain actors or social groups. The analysis strategy of the candidates' images in Local-Government Election 2018 used Theo van Leeuwen's analysis. It was the deletion which consisted of two strategies: suppression and backgrounding. In this research, suppression could be analyzed through 3 things. They are omission of passive agents, non-finite clause arrangement, and omission of the benefited social actors.

\section{Deletion}

This system refers to inclusion and exclusion processes of certain social actors, in this case the candidate of the 2018 LGE . This system influences the readers' understandings about the intentions of the reports. It means there are several benefited or aggrieved parties due to the reports of 2018 Local-Government Election in 
Central Java found in three online mass media: Kumparan, Tribun, and Sindo. Here is the image graphic of both candidates in the election by having deletion strategy.

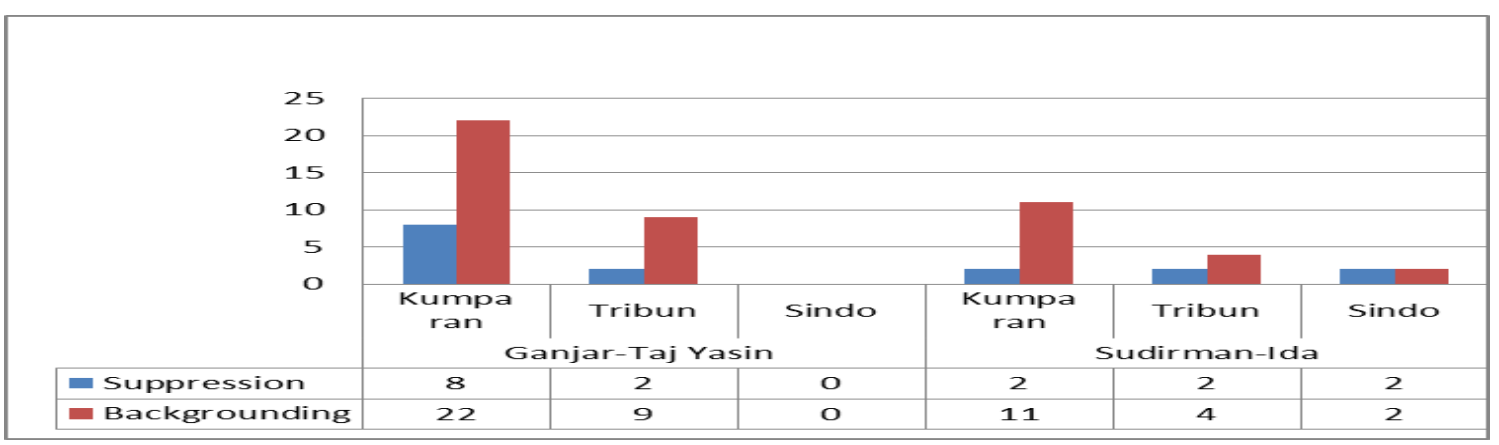

Figure 1. Deletion of the 2018 Central Java Government Election Social Actors

Meanwhile, the implementation of the deletion system of the candidates is as follows.

\section{Suppression}

The most frequently applied suppression strategy by Kumparan.com in creating images for both candidates was mostly seen for Ganjar Pranowo-Taj Yasin with specific purposes.

\section{Omission of Passive Agents}

This omission in the reporting discourse could influence the meaning for the readers. This omission was done with certain purposes or motives. The omission of the social actor, Ganjar Pranowo, is also seen in this excerpt.

(1) Ganjar Claimed That During His 5 Year Government, $\mathrm{He}$ Has Succeeded To Internalize The Democracy Values, To Create Transparent Government, And To Provide Social Services. Hal Ini Akan Terus Dilanjutkan Untuk Menciptakan Keadilan Sosial Bagi Seluruh Warga Jateng.

(Data 8)

(Kumparan, "Debat Pamungkas, Ganjar dan Sudirman 'Ribut' soal Petani dan Nelayan" June 21, 2018).

The excerpt is in the form of passive voice with the subject "hal ini" (this matter) which is a noun phrase. The actor in the excerpt refers to "warga Jateng" (Central Java citizens) in which in this context is the benefited object. In the excerpt, the omitted passive agent is "Ganjar Pranowo-Taj Yasin".

In the excerpt, the utterance "Hal ini akan terus dilanjutkan untuk menciptakan keadilan sosial bagi seluruh warga Jateng" actually refers to Ganjar Pranowo. However, in the excerpt, the figure of Ganjar Pranowo is not attached even in the form of a pronominal persona. Actually, the excerpt could have been written "Hal ini dilanjutkan oleh Ganjar untuk menciptakan keadilan sosial bagi seluruh warga Jateng".

The omission ot the social actor in this positive-intentional context is a strategy to not repeatedly show the social actor. In this case, the social actor's name, Ganjar Pranowo, is omitted. This omission makes it an abstract or unclear utterance because of the agent omission.

Then, deletion implementation is also found in Sindonews.com mass media. This strategy omitted the social actor, Ganjar Pranowo, but implicitly it promotes Sudirman Said-Ida Fauziyah. Here is the analysis.

(2) Diharapkan Pula Jateng Ke Depan Menjadi Provinsi Yang Bukan Hanya Saja Maju, Tetapi Juga Memiliki Pemimpin Yang Bersih Dan Tata Kelola Pemerintahan Yang Baik, Yakni Good Governance.

(Data 28)

(Sindo, "Jelang Pilkada, Sudirman Said Temui Anies Baswedan” June 26, 2018)

The excerpt is in the form of passive voice with the verbal predicate affixed by "di-". Actually, the utterance is uttered by an agent that is intentionally omitted in the utterance. He is Anis Baswedan. However, in the excerpt with the plural sentence form, the clause with the denial conjunction shows the "pemimpin yang 
bersih dan tata kelola yang baik" (clean and good governance leader) actor. It means the actor refers to Sudirman Said and the utterance marginalizes Ganjar Pranowo explicitly.

From the excerpt, it could be seen that there is a social actor omission, Ganjar Pranowo. The utterance is also the explanation and hope of Anies Baswedan. In addition to the agent omission, occurred for Anis Baswedan, implicitly, the point of the utterance is to justify that Ganjar's government has not been completely meeting good governance elements. By attaching a diction "pemimpin bersih" (a clean leader), it makes the utterance to have an insinuation to Ganjar. However, beyond the strategy, Sudirman Said-Ida Fauziyah are benefited because of the persuasion done by Anies Baswedan.

When previously, in the utterance has an agent omission occurred in Ganjar Pranowo, in Sindones.com online mass media, a suppression strategy to omit Sudirman Said-Ida Fauziyah as the agents was found. Here is the analysis.

(3) Langkah Ini Dilakukan Untuk Mempersiapkan Diri, Apabila Dalam Tahapan Pilgub Selanjutnya, Yakni Rekapitulasi Suara Terdapat Hal Yang Tidak Sesuai Fakta Di Lapangan.

(Data 97)

(Sindo, "Sudirman-Ida Berniat Kumpulkan Bukti Pelanggaran Pilgub Jateng" June 27, 2018)

Based on the excerpt, there are no agents found in it. The subject in the utterance is a phrase "langkah ini" (this step), meanwhile the predicate is in a passive verb with "di-". From the utterance, it could be seen that the omitted agents are "Sudirman Said-Ida Fauziyah".

From the utterance, it could be known that the omitted passive agents are Suidrman Said-Ida Fauziyah. From the title, the utterance context benefits Sudirman-Ida by showing them as the victims. However, as explained previously that SindoNews.com tends to be careful in choosing the diction to avoid any marginalizing impression or siding impression for certain government candidates. It includes the social actors, Sudirman-Ida Fauziah, as the main agents in the omitted news discourse. However, the passive-agent omission does not put other party at disadvantage, such as Ganjar-Taj Yasin. This omission functions to limit the repetitive existence of certain social actors' names in Sindonews.com mass media report.

\section{The Benefited Social Actor Omission}

The omission process of a social actor or group in the utterance could influence the presented meaning. It influences significantly when the social actors or certain groups whom are omitted are also the benefited social actors. Here is the analysis

(4) Dengan Amunisi Korupsi E-Ktp, Mantan Menteri Esdm Itu Mengingatkan Agar Warga Jateng Memilih Pemimpin Yang Bisa Menjadi Teladan Dan Tidak Memiliki Risiko Hukum Di Kpk.

\section{(Data 4)}

(Kumparan, "Adu Teriakan Pendukung: e-KTP vs Pecatan Menteri saat Debat Pilgub", May 3, 2018).

The utterance has a subject "mantan Menteri ESDM" (the ex of Ministry of Energy and Mineral Resources) with predicate "mengingatkan" and the object is in the benefited actor whom is intentionally omitted. From the utterance, the benefited actor is intentionally omitted. He is Ganjar Pranowo. It happens since Ganjar Pranowo ever had a legal risk with Corruption Eradication Omission.

In the utterance, Sudirman Said (written as the ex of Ministry of Energy and Mineral Resources) is an agent whom is highlighted.

Meanwhile, the objects upon Sudirman Said's statement, "agar warga Jateng memilih pemimpin yang bisa menjadi teladan dan tidak memiliki risiko hukum di KPK" is a deletion form of the actor, Ganjar Pranowo. It is strengthened by a clarification phrase of the object, "memiliki risiko hukum KPK". Besides that, the subordinate clause in the beginning, "dengan amunisis korupsi e-KTP", also makes more detail description because Ganjar Pranowo was dealing with legal process of e-KTP.

As what Rahmini argued (2011), the main purpose of each CDA is to reveal the implicit 
matter in a discourse. In the utterance, it is not written implicitly that "Sudirman Said" asks supports from the citizens because he is uninvolved in e-KTP case. However, explicitly it could be known so because of the phrase remark has purpose (to ensure the Central Java citizens to choose a leader whom could be an exemplary and does not have any legal risk in Corruption Eradication Commission.

The use of a personal pronoun "mantan Menteri ESDM" also has pro and contra sides of the demanded images to show. In another side, the ex minister, Sudirman Said, has strong correlation with Freeport acquisition. However, Sudirman Said, at that time, gained supports from Mahfud MD. In the other side, Sudirman Said also could dismiss Petral which was full of corruption cases. He also could provide more profits for Pertamina. Regardless of the pronoun explaining about Sudirman Said, the social actor, Ganjar Pranowo, is more marginalized in the utterance. Therefore, it could be said that the utterance shows the positive images of Sudirman Said and negative images for Ganjar Pranowo.

The same things occurred in the utterance with Sudirman Said as the agent as follows.

(5) Ia Juga Menyebutkan, Pemerintahan yang Baik Sebaiknya Tidak Terlalu Senang dengan Data Statistik yang Menunjukkan Jumlah Kemiskinan Menurun.

(Data 3)

(Kumparan, "Ganjar dan Sudirman Adu Solusi Atasi Kemiskinan di Debat Pilgub" May 3, 2018.

Meanwhile, from the excerpt, it could be known that the actor's position, Ganjar Pranowo, is intentionally omitted. It is proven from the previous utterance "pemerintah yang baik" (good governance). It has a single reference, Ganjar Pranowo. In this competitive context, the insinuative nuances between two candidates were frequently occurred.

The deletion aspect based on the utterance is indicated by a statement of the subject, Sudirman Said, with irony language style. It was addressed to target Ganjar Pranowo. In the phrase "pemerintah yang baik" (good governance), it is seen the social actor, Ganjar
Pranowo, is omitted. However, the meaning of the phrase is attahced implicitly or indirectly. As what O'Halloran argued (2005) that omission of a social actor in a text tends to make readers confused. The phrase "pemerintah yang baik" (good governance) in fact states the intention that Ganjar's government is not a good governance. It means the good governance based on Sudirman Said's version is a governance that is not satisfied by the decreasing statistics data of poverty. In several previous reports, there were shown that the first candidates, Ganjar Pranowo-Taj Yasin, were still dominating the major survey. Their attitudes also showed their pride with their statistical achievements. By the existence of a good governance and a bad governance, the utterance shows more positive images for Sudirman SaidIda Fauziah.

\section{Nominalization}

Nominalization could be used to omit certain social actor or group by changing the verbs into nouns for specific purposes. The noun formation could change the readers' perspectives.

(6) Having The Answers, Taj Yasin ReEmphasized What Were Seen Were The Achievements. Karena Menurutnya Penurunan Itu Hasil Terbaik, Bahkan Lebih Tinggi Dari Dki Jakarta.

(Data 10)

(Kumparan, "Mengingat Kembali Panasnya Debat Pertama Pilgub Jateng 2018" May 3, 2018).

According to Theo van Leeuwen analysis, the deletion could be found through nominalization. In the utterance of the report, it is written in the form of a nominalization, "penurunan itu hasil terbaik, bahkan lebih tinggi dari DKI Jakarta". It has purposes to delete the social actor, Taj Yasin as the agent or as the doer. The noun "penurunan" (decrease) becomes the object without the existence of Taj Yasin. However, it will turn into the object once Taj Yasin becomes the subject.

The excerpt is to defend Sudirman Said's criticism about "tidak adanya perubahan ke arah 
kemajuan selama lima tahun pemerintahan Ganjar". In this reporting discourse context, Ganjar-Taj Yasin's position is recessive due to criticisms and resolutions of Sudirman-Ida Fauziyah. It makes Taj Yasin states it as a defense by referring the data. Taj Yasin's action becomes a boomerang for him when Sudirman Said utters about "pemerintahan yang baik bukanlah pemerintahan yang hanya percaya pada data". Sudirman's statement which tends to be skeptic with data could trigger supports for any citizens whom do not satisfy with Ganjar's governance performance.

When Kumparan.com frequently omits Ganjar Pranowo and accentuates Sudirman Said, TribunNews.com has different ways to create images of the Central-Java government election candidate 2018. Here is the analysis through the excerpts as follows.

\section{Backgrounding}

The backgrounding as a part of suppression strategy could be seen from the clauses' existences on the subordinate clauses. It means the showed social actors are raised in other places in the same clauses. Those two realizations bring social actors into different level. However, both of them have roles to reduce the numbers of certain social actors explicitly.

The deletion strategy of backgrounding aspect could be seen from the phrase existence which refers to certain social actors. Usually, there will be written elements dealing with positions, histories, or certain achievements. Therefore, backgrounding strategy does not write the names of the social actors directly.

The first candidate couple, Ganjar Pranowo-Taj Yasin, have undergone backgrounding in Kumparan.com. Several of them could create images even marginalize the actor, Ganjar Pranowo. Here is the analysis.

(7) KPK Kembali Memanggil Sejumlah Anggota DPR dalam Proses Penyidikan Korupsi e-KTP. Setidaknya Ada Enam Nama Mantan Anggota dan Anggota Aktif DPR RI yang Diperiksa KPK sebagai Saksi untuk Tersangka Irvanto Hendra Pambudi Cahyo dan Made Oka Masagung.

(Data 12)

(Kumparan, "KPK Panggil Ganjar Pranowo hingga Aziz Syamsuddin Terkait Kasus e-KTP” June 5, 2018)

From the excerpt, it could be known that the phrase "mantan anggota aktif DPR RI yang diperiksa KPK" (the ex-active House members under CEC investigation) refers to Ganjar Pranowo. It is proven since Ganjar Pranowo was the House members for two periods, 20042009 and 2009-2014. However, in the second period, he did not continue it because he was elected as the Central Java governor.

The applied strategy does not benefit Ganjar Pranowo-Taj Yasin's team because they raise e-KTP topic which could threat them electability as the incumbents. It means although the name of Ganjar Pranowo is not shown directly and replaced by a phrase "mantan anggota aktif DPR RI yang diperiksa KPK", it in fact makes Ganjar's position clear that he ever had legal risk due to e-KTP corruption case. There are also other marginalization directed for Ganjar Pranowo with his case as follow.

(8) Adalah Cagub Sudirman Said yang Menyinggung Ganjar Pranowo yang Juga Mantan Wakil Ketua Komisi II DPR Saat Proyek e-KTP Bergulir, Sering Bolak-Balik Dipanggil KPK dalam Kasus Korupsi yang Melibatkan Banyak Anggota DPR dan Pejabat Kemendagri.

(Data 13)

(Kumparan, "Debat Memanas, Sudirman Said Serang Ganjar soal Korupsi e-KTP" May 3, 2018)

It is same with the previous analysis, the excerpt also corners Ganjar Pranowo. The phrase addition "mantan Wakil Ketua Komisi II DPR saat proyek e-KTP bergulir", which refers to Ganjar Pranowo, strengthens the correlation between Ganjar and e-KTP corruption case. Besides Ganjar Pranowo, there is his vice, Taj Yasin, whom also undergoes backgrounding. Here is the analysis.

(9) Untuk Calon Wakilnya, Megawati Mempercayakan Posisi Itu kepada Putra 
Ulama Karismatik Maimoen Zubair, Taj Yasin Maimoen.

(Data 14)

(Kumparan, "Diterpa Isu e-KTP, Ganjar Pertahankan Kursi Gubernur Jateng” June 27, 2018)

At tis time, the actor, Taj Yasin, as the incumbent vice is positively imaged with the phrase "putra ulama karismatik Maimoen Zubair, Taj Yasin Maimoen" (the son of charismatics Islamic theologian, Maimoen Zubair, Taj Yasin Maimoen). Likewise, the vice of Sudirman Said, Ida Fauziyah, who is positively imaged through backgrounding.

\section{CONCLUSION}

Based on the findings, both candidates of the Central Java Local Government Election 2018, Ganjar Pranowo-Taj Yasin and Sudirman Said-Ida Fauziyah, found in three online mass media are dominated by backgroudning strategy. Kumparan.com used backgrounding which referred to Ganjar-Taj Yasin. It connected them to $e$ KTP case so it could influence the electability stability of Ganjar-Taj Yasin. Meanwhile, TribunNews.com used backgrounding to strengthen Ganjar-Taj Yasin's electability. It was proven by the backgrounding, "petahana, politikus PDIP" or incumbent. SindoNews.com was not seen to have exclusion or to marginalize certain social actors. Therefore, it could be said that Kumparan.com created negative images for Ganjar-Taj Yasin while positive images for Sudirman-Ida. Meanwhile, Tribunnes.com created positive images for Ganjar-Taj Yasin and negative images for Sudirman-Ida. SindoNews.com tends to be neutral.

\section{REFERENCES}

Alwasilah, Chaedar. (1997). Politik Bahasa dan Pendidikan. Bandung: PT Remaja Rosdakarya.

Assidik, G. Kurnia dan B. Wahyudi J.S. (2016). "Citra Publik Presiden Republik Indonesia pada Pemberitaan di Harian Suara Merdeka, Tabloid Tempo, dan
Harian Republika: Kajian Analisis Wacana Kritis Model Norman Fairclough. Seloka: Jurnal Pendidikan Bahasa dan Sastra Indonesia. Vol. 5. No. 2, hlm $201-2015$.

Bestari, Titan Ratih. (2014). "Pemberitaan Gubernur Bali, Mangku Pastika, dalam Surat Kabar Bali Post: Analisis Strategi Eksklusi-Inklusi Theo Van Leeuwen". eJournal Universitas Pendidikan Ganesha JPBSI. Vol 2. No. 2.

Bustam, Muhammad Rayhan. (2013). "The Exclusion Strategies Of The Representation Of Social Actors In The Case Of FPI's Rejection To Lady Gaga's Performance In Indonesia On The Jakarta Post Newspaper Headlines (A Cda Approach)". International Journal of Language Learning and Applied Linguistics World (IJLLALW). Vol. 4, No. 3, hlm. 33 - 49 .

Denzin, Norman K. (eds). (2000). Handbook of Qualitative Research. California: Sage Public.

Dinastiti, F. Evi dan Hari Bakti M. (2016).

"Analisis Wacana Kritis Pemberitaan Harian Suara Merdeka, Harian Republika, Harian Kompas, dan Tabloid Derap Guru dalam Pembentukan Citra Guru". Seloka: Jurnal Pendidikan Bahasa dan Sastra Indonesia. Vol 5. No. 2, hlm. $136-147$.

Fairclough, Norman. (2003). Language and Power 'Relasi Bahasa, Kekuasaan, dan Ideologi. Gresik: Boyan Publishing.

Ghafur, Abd. (2016). "Critical Discourse Analisys; Sebuah Model Analisis Sosial Kritis dalam Teks Media". OKARA Journal of Languages and Literature, Vol. II, hlm 177 - 194.

Hariyani dan Hari Bakti M. (2016). "Pembentukan Reputasi Calon Presiden 2014 dalam Berita di Media Massa Online:Kajian Wacana Kritis". Lingua. Vol. XII. No. 2, hlm. 168 - 179.

Hasanah, Alif dan Hari Bakti M. (2017). "Konstruksi Realitas Seratus Hari Pertama Pemerintahan Jokowi-Jusuf 
Kalla di Media Online: Analisis Wacana Kritis Model Norman Fairclough". Seloka. Vol. 6. No. 3, hlm. 233 - 243.

Leeuwen, Theo Van. (2008). Discourse amd Practise. New York : Oxford University Press.

Littlejohn., Stephen W. (2002). Theories of Human Communication : Seventh Edition. California: Wadsworth Group.

Louw, P Eric. (2001). The Media and Cultural Production. London: SAGE Publications Ltd.

Mardikantoro, Hari Bakti. (2014). "Analisis Wacana Kritis pada Tajuk (Anti) Korupsi di Surat Kabar Berbahasa Indonesia“. LITERA. Vol 13. No. 2, Hlm. 215 - 225.

Mayasari. (2014). "Tweet Farhat Abbas dalam Akun Twitter Pribadi Farhat Abbas: Analisis Wacana". Jurnal Ilmiah Solusi. Vol. 1. No. 3, hlm. 8 - 23.

Ritongga, Rajab. (2014). "Pertarungan Makna pada Konvensi Parti Demokrat dalam
Mencari Calon Presiden Republik Indonesia". Jurnal Komunikasi Malaysian Journal of Communication. Vol. 30, No. 2, hlm. $201-220$.

Santoso, Wahyu Joko. (2018). "Representasi Aktor Sosial dan Pertarungan Makna dalam Pemilihan Umum Kepala daerah (Pilkada) Tingkat Provinsi di Pulau Jawa pada Tahun 2018 di Media Massa Daring dalam Perspektif Analisis Wacana Kritis Model Theo van Leeuwen”. KOLITA 16, hlm. $489-494$.

Sobur, Alex. (2006). Analisis Teks Media: Suatu Pengantar untuk Analisis Wacana, Analisis Semiotik, dan Analisis Framing. Edisi Revisi. Bandung: Remaja Rosdakarya.

Sudaryanto. (2015). Metode dan Aneka Teknik Analisis Bahasa: Pengantar Penelitian Wahana Kebudayaan secara Linguistis. Yogyakarta: Sanata Dharma University Press. 